\title{
Green building standard assessment at a higher education institution
}

\author{
Rahmat Nurcahyo $^{1,{ }^{*}}$, Nurmala Sari ${ }^{1}$, Muhammad Habiburrahman ${ }^{1}$ and Ellia Kristiningrum $^{2}$ \\ ${ }^{1}$ Department of Industrial Engineering, Faculty of Engineering, Universitas Indonesia Kampus UI \\ Depok 16424, Indonesia \\ ${ }^{2}$ National Standardization Agency for Indonesia, BPPT 1st building, Jakarta 10340, Indonesia
}

\begin{abstract}
The environmental impact caused by the construction of the building is very large. A building will require great energy, electricity, water, and also produces large amounts of waste. To prevent that, a concept of development that caring the state of the environment is needed. The concept is known as the green building concept. This research was conducted to assess academic buildings at a higher education institution using green building assessment. The criteria for assessment is based on Greenship Rating System which consists of six categories such as appropriate site development, energy efficiency and conservation, water conservation, material resources and cycle, indoor air health and comfort, building and environment management. The results of this research are comparison between the green building actual and ideal conditions using gap analysis. Action plans also developed to achieve the expected green conditions according to Green Building Certification.
\end{abstract}

\section{Introduction}

The current global warming is a world issue. The phenomenon of global warming is the rising temperature of the earth's surface due to the increased greenhouse effect. Based on data from the World Green Building Council, throughout the world, building donate $33 \%$ of $\mathrm{CO} 2$ emissions, consume $17 \%$ water, $25 \%$ of wood products, energy use by $30-40 \%$ and $40-50 \%$ utilization of raw materials for the construction and operation. [1] Energy consumption in the building sector can be quite large for lighting or air conditioning. A source of energy for the building comes from the consumption of fossil fuels that emit carbon dioxide in significant quantities. In addition, the construction sector also contributed greatly to the consumption of water and electricity in a region.

Buildings also have a significant impact on human health. Indoor air typically contains between 2 and 5-and occasionally greater than 100-times more pollutants than outdoor air. As a result, poor indoor air quality in buildings has been linked to significant health problems such as cancers, asthma, Legionnaires' disease and hypersensitivity pneumonitis [2]. One idea that to reduce global warming and environmental degradation is an environmentally friendly building concept, called green building. Green building has many

\footnotetext{
*Corresponding email: rahmat.nurcahyo26@gmail.com
} 
terms such as "sustainable development" s (real estate industry), "green building" (US term), "sustainable building" (UK and Australia term), "sustainable architecture" and "sustainable construction". [3]

Green Building Council Indonesia (GBCI) is an independent institution (nongovernment) and non-profit (non-for-profit) which one of the programs is organizing the Green Building Certification activities in Indonesia by Indonesian special assessment tools called Greenship Rating System. Several previous research related to the implementation of Green Building in Indonesia such as on Civil Engineering Institut Teknologi Surabaya (ITS), building H ITS and construction project in Surabaya. [4]

\section{Green Building}

The implementation of Green building concept is not only used in design and construction stage but also the operation stage [5].According to The United States Environmental Protection Agency (USEPA), green building is the practice of creating structures and using processes that are environmentally responsible and resource-efficient throughout a building's life-cycle from siting to design, construction, operation, maintenance, renovation and deconstruction. This practice expands and complements the classical building design concerns of economy, utility, durability, and comfort. Green building is also known as a sustainable or high performance building. [6]

According to Green Building Council Indonesia (2010) [7], the green building is a new building that is planned and carried or a building that already built which is operated by taking into environmental factors or the ecosystem and meet the performance such as appropriate site development, water saving, energy saving, waste reduction, indoor air quality. The benefits of green building are related to environment, economics and social. [8]

There are three types of green building benefits such as environment, economic and social. Example of environmental benefits of green building are reduction of harmful gas emissions and waste. Economic benefits of green building such as energy and water savings, increased property values, increased property values. Social benefits of green building such as improved health, and healthy lifestyle [9]. The benefits are achieved through some approaches such as using solar panels, public transportation facilities provision, stormwater and greywater management.

Greenship Rating System is a tool to assess a building based on green building concept. The rating system containing a grain of aspects of the so-called rating and assessment of each item has a point value or credit point. There are several types of the rating system such as the rating system for new building, existing building, interior space, homes, and the draft for sustainable neighborhood. In this research, assessment tools used is for the existing building.

There are six assessment categories on greenship rating system for existing building, such as appropriate site development, energy efficiency and conservation, water conservation, material resources and cycle, indoor air health and comfort, building and environment management. Each assessment category has several prerequisite and criteria which related to scoring. Some categories only have maximum scoring while other categories have maximum and bonus points.

Appropriate site development (ASD) category have two prerequisites and 8 criteria with 16 points maximum. Energy efficiency and conservation (EEC) category have two prerequisites, five main criteria with 36 maximum points and two bonus criteria 8 bonus points. Water conservation (WAC) category have one prerequisite, seven main criteria with 20 maximum points and one bonus criteria with 2 bonus points. Material resources and cycle (MRC) category have three prerequisites, five main criteria with 12 maximum points. 
Indoor air health and comfort (IAHC) have one prerequisite and eight criteria with 20 maximum points. Building and environment management (BEM) have one prerequisite and five criteria with 13 maximum points.

\section{Research Object and Method}

One of the important building in higher education institution is academic building usually being used for classroom activities. Academic building is one of the buildings which use substantial energy. This is caused by the demands of academic services and comfort in the learning process, including the beauty of the room (lighting systems), the comfort of air (air system), complete facilities and others. The necessity to reduce energy use by academic building become the background of this research.

This research objective is to apply green building assessment criteria on the academic building at Faculty of Engineering, Universitas Indonesia. The assessment purpose is to determine the level of application for the green building concept on these buildings and as a reference to achieve green building certification.

There are two steps for assessment of the actual state of the building to the standards Greenship Rating System. The first step is observing the actual conditions that exist in the building that are fit to the items in the category of greenship existing building. The second step after reviewing the actual condition of the buildings is awarding of points for each category that is adjusted to the existing standards in the category of greenship existing building. After the assessment, the analysis carried out for each criteria in the category of greenship existing building along with the action plans that are suggested to meet the standard points.

\section{Results and Discussion}

There are two buildings at Faculty of Engineering Universitas Indonesia that selected as the objects of this research. The two buildings are academic buildings. The result of the assessment of the first building is 38 points out of 117 points in total so that the percentage of green condition is $32 \%$. The result of assessment of the second building is 20 points out of 117 points in total, so that the percentage of green condition is $17 \%$. Detail of assessment result for each criteria for the two buildings is shown in table 1.

Table 1. Results of Assessment Points

\begin{tabular}{|c|c|c|c|}
\hline Criteria & $\begin{array}{c}\text { Maximum } \\
\text { Points }\end{array}$ & $\begin{array}{c}\text { The First } \\
\text { Building }\end{array}$ & $\begin{array}{c}\text { The Second } \\
\text { Building }\end{array}$ \\
\hline Appropriate Site Development (ASD) & 16 & 4 & 4 \\
\hline Energi Efficiency \& Conservation (EEC) & 36 & 21 & 6 \\
\hline Water Conservation (WAC) & 20 & 2 & 1 \\
\hline Material Resources and Cycle (MRC) & 12 & 4 & 4 \\
\hline Indoor Health and Comfort (IHC) & 20 & 3 & 3 \\
\hline Building Environment Management (BEM) & 13 & 4 & 2 \\
\hline Total & $\mathbf{1 1 7}$ & $\mathbf{3 8}$ & $\mathbf{2 0}$ \\
\hline
\end{tabular}


The analysis carried out for each category in Greenship Existing Building along with the action plans that are suggested to meet the maximum points. Based on the data of ASD criteria, the gap points are caused by several factors, including no restrictions on the use of motor vehicles, the number of bicycle parking and facility doesn't meet the GBCI standard, the formation of plants in the green open land is not accordance to Permen PU No. $5 / \mathrm{PRT} / \mathrm{M} / 2008$, clause 2.3.1, the lack of a system for treating stormwater runoff, the absence of Standard Operation Procedure for pest and weed control, unavailability of nondomesticated habits and animals.

The gap points at EEC criteria are caused by several factors, including recommissioning have never done on the cooling system, the lack of written Standard Operation Procedure for air conditioning systems, MVAC system is not used, no submetering for energy consumption in EC buildings.

Based on the data of WAC criteria, the gap points are caused by several factors, including the absence of Standard Operation Procedure for the plumbing system on a regular basis, no historical data of water use because the new water metering tool is just installed, unavailability of water recycling system which output is equivalent to the clean water standards.

The gap points at MRC criteria are caused by several factors, including still using R22 in air conditioning systems which ODP value $=0.05$, unavailability of reports for used goods delivery.

Based on the data of IHC criteria, the gap points are caused by several factors, including the lack of measurement of the quantity and quality of indoor air levels to meet the requirements of SNI (Indonesia National Standard) and Permenkes (Indonesia Ministry of Health), no survey for the level of convenience to building user as a means of feedback for improvement.

The gap points at BEM criteria are caused by several factors, including innovation applications to improve the quality of the building is still needed to be developed further, unavailability of Standard Operation Procedure and training which include efforts to meet the criteria, unavailability of Greenship Professionals involved in operations and maintenance.

\section{Conclusion}

This research was conducted to assess academic buildings at Faculty of Engineering Universitas Indonesia using green building assessment. There are two building selected as the objects. The results of achievement points on the first building measurement is $32 \%$. The results of achievement points on the second building measurement is $17 \%$. Minimum points to obtain a certificate Greenship Bronze level is $35 \%$, so there is a gap condition in both buildings.

The action plan needs to be done to achieve green building certification at least $35 \%$ points, among others:

- Appropriate Site Development: An effort to reduce the use of private vehicles, making decent support facilities to encourage the users building to use the bike, utilization of vacant land to be planted with vegetation, making systems for treating stormwater runoff.

- Energy Efficiency \& Conservation: Installation of metering tools in EC building for controlling electrical energy consumption, establish the Standard Operation Procedure for air-conditioning system covering operation, maintenance, and reporting. 
- Water Conservation: Establish the Standard Operation Procedure for piping systems periodically to prevent leakage and wastage of water, study for water recycling system that could be used for irrigation and flushing toilets.

- Material Resources and Cycle: Replace refrigerant materials with non-CFC material, establish Standard Operation Procedure which governs the way the distribution of second-hand goods which still can be recovered.

- Indoor Health and Comfort: Measurement for air quality in the room at regular intervals, as well as measurements of dust levels.

- Building Environment Management: Socialization and training related to the concept of green building so that every employee, staff and building occupants understand clearly the application of the concept of green building so it is easier to make and understand the Standard Operation Procedure include efforts to comply with the criteria in greenship.

\section{Acknowledgement}

Supported by Hibah PITTA 2018 Universitas Indonesia, contract number 2513/UN2.R3.1/HKP.05.00/2018.

\section{References}

1. M. Samer. CIGR Journal. 15, 2 (2013).

2. M. Baum. Green Building Research Funding: An Assessment of Current Activity in the United States, http://www.usgbc.org/Docs/Archive/General/Docs2465.pdf. (2006).

3. A. Vinyangkoon. Commercial Green Building The Value Added Gap Perspective. Thesis, Department of Real Estate Management (2012).

4. F. N. Wakhidah., C. Utomo. Jurnal Teknik Pomits. 3, 2 (2014).

5. T. S. Surjana. Jurnal Arsitektur Universitas Bandar Lampung. 2, 3 (2013).

6. R. Zigenfus. Element Analysis of the Green Building Process. Thesis, Rochester Institute of Technology, Rochester, NY, (2008).

7. Green Building Council Indonesia. Greenship untuk bangunan baru versi 1.2. Ringkasan kriteria dan tolak ukur. Retrieved from: http://gbcindonesia.org/greenship/rating-tools, (2014).

8. N. S. A. Adiwoso, Prasetyoadi, S. Perdana. Towards Indonesia Sustainable Future through Sustainable Building and Construction (2010).

9. S. D. Sentman. The Journal of Israel Innovation, 1 (2009) 